\title{
Contemporary Chinese Youth and the State
}

\section{STANLEY ROSEN}

$\mathrm{H}$ AVING PUT A VERY successful Olympics in the rearview mirror, China entered 2009 with a set of new challenges, brought on in part by the worldwide economic crisis and the resulting demands to ensure necessary employment levels and in part by the familiar issue of maintaining social stability. While the hope, presumably, was to move reasonably smoothly from the Olympics of August 2008 to the celebration of the sixtieth anniversary of the founding of the People's Republic of China in October 2009, the Chinese media has instead become proactive in alerting local officials and the general public that China is entering "a peak period for mass incidents” (quntixing shijian, 群体性事件), with further warnings that a single national-level event, handled poorly, could “resonate" (gongzhen, 共振) into a threat to overall social stability and a serious political crisis. ${ }^{1}$

The timing is particularly sensitive because 2009 will also see the anniversaries of the May Fourth Movement (1919), the Tiananmen Square protests and the subsequent bloody military assault (April-June 4, 1989), and the bombing of the Chinese embassy in Belgrade by NATO forces, led by the United States (May 7, 1999). Each of these anniversaries is worrisome to China's political leadership, albeit for different reasons, and each one has the potential to mobilize different segments of China's youth population, including more than 6 million current-year university and college graduates, who will join those from 2008 who are still hunting for jobs. ${ }^{2}$ While the twentieth anniversary of what is now widely known as liu si (六四, or June 4), or “Tiananmen," is likely to provoke a response from more liberal elements within the population, ${ }^{3}$ and appears to be of generally less interest to most youth today, the tenth

Stanley Rosen (rosen@usc.edu) is Director of the East Asian Studies Center and Professor in the Department of Political Science at the University of Southern California.

${ }^{1}$ Dong Ruifeng, "Early Warning about Mass Incidents," Liaowang xinwen zhoukan [Outlook Weekly], no. 1, 2009; Ariana Eunjung Cha, “As China’s Jobless Numbers Mount, Protests Grow Bolder: Economic Woes Shining a Light on Social Issues," Washington Post, January 13, 2009; “The Year of Living Dissidently," The Economist, January 17, 2009, 42-43.

${ }^{2}$ Dong, "Early Warning about Mass Incidents."

3"Charter 08," a document released on December 10, 2008, and signed by more than 2,000 Chinese citizens, including some mid-level government officials, advocated the elimination of oneparty rule and its replacement by a democratic system that would protect human rights. The party's strong reaction suggested that it saw this document, and the willingness of so many individuals to sign their names openly, as a warning of additional challenges to come in 2009. For a translation of the charter and government reaction, see Perry Link, "China’s Charter 08," New York Review of Books, January 15, 2009, 54-56. 
anniversary of the NATO bombings would appeal more directly to those youth who have been labeled anything from “angry youth" (fenqing, 愤青) to “neocon nationalists." The May Fourth anniversary is particularly intriguing because it potentially appeals to all youth, regardless of their political persuasion. This event, considered by many to be the origin of modern Chinese nationalism, was spearheaded by the student movement and predated the founding of the Chinese Communist Party by two years. As a result, youth, particularly those in elite universities, can lay claim to having a longer tradition of revolutionary credentials than the party itself, and at times they have felt a strong obligation to defend China from hostile external forces or to rectify the party-state when government policies have wavered onto the wrong path. Youth intervention, particularly among students, was a feature of both pre- and post-1949 China, and Mao Zedong did not hesitate to tap into this tradition when he needed foot soldiers for his Cultural Revolution against entrenched party opposition $(1966-76) .^{5}$

Reflecting the increasing pluralization of Chinese society after thirty years of reform, Chinese youth in 2009 are far from unified in their belief systems or behaviors. At the same time, a more general understanding of the attitudes and behaviors of Chinese youth has proved elusive for observers, both inside and outside China. Up until mid-2008, it was common to find youth under attack in the Chinese media, characterized as the "me generation" and criticized for being "reliant and rebellious, cynical and pragmatic, self-centered and equality-obsessed," as well as "China's first generation of couch potatoes, addicts of online games, patrons of fast food chains, and loyal audiences of Hollywood movies." ${ }^{\prime 6}$ The Sichuan earthquake of May 12, 2008, however, seemingly changed everything: The same media outlets that had written off such youth now reversed themselves to extol their virtues, while noting, not just in passing, that their altruistic behavior was not surprising because they had learned the virtues of "great compassion, benevolence, and gallantness" from imbibing traditional Chinese culture, and that, after all, they had "fully enjoyed the achievements of China's 30 years of reform and opening up." ${ }^{, 7}$ Still, it is difficult to reconcile these compassionate youth with those who are angry. Indeed,

\footnotetext{
${ }^{4}$ Evan Osnos, “Angry Youth: The New Generation's Neocon Nationalists," New Yorker, July 28, 2008, 28-37.

${ }^{5}$ In an important sense, these three anniversaries are linked in that both the 1989 and 1999 demonstrations occurred in the shadow of May Fourth, which always elicits discussions of patriotism and the defense of China.

6“The 'Me Generation," Beijing Review, February 28, 2008. A similarly titled article, written by Simon Elegant, appeared in Time magazine on June 26, 2007, and attracted considerable attention on Chinese blogs. See the original article and translations of several blog posts on the blog EastSouthNorthWest, August 1, 2007.

7“Complete New Appraisal of the Post-80's Generation," People's Daily (English ed.), June 4, 2008. Presumably, the publication of this favorable appraisal of contemporary Chinese youth on June 4 was not coincidental.
} 
reflecting the continuing influence of the recent past, some Chinese critics have referred to Internet-savvy nationalists as "online Red Guards" infected by a "populist virus."

It seems clear that there are competing and often contradictory influences shaping the attitudes and values of young Chinese today, particularly in the wealthy coastal areas. They have become very internationalist in their outlook, and they are strongly affected by global trends. Likewise, they are very pragmatic and materialistic, largely concerned with living the good life and making money. The third competing influence, most often called nationalism in its more extreme form, represents a broader impulse and encompasses not only the defense of China against perceived enemies from abroad, but also the kind of love of country and self-sacrifice in support of those most in need that was evident in the volunteerism that followed the earthquake. Chinese youth have shown that they are capable of exhibiting all of these tendencies at different times, depending on the circumstances, or even at the same time. As some interviewees noted, even those youth who felt they had to "show patriotism" by honoring the shortlived attempt to boycott Carrefour, the French superstore, in response to French interference with the Olympic torch relay during its Paris run, made sure to use up all their discount coupons and finish their shopping prior to the May 1 boycott. $^{9}$

While public opinion surveys have certainly revealed the importance of money and material things in the lives of Chinese youth, at the same time, they suggest a young generation desperate to believe in something and very willing to make sacrifices if they are persuaded that the cause is just. Thus, an opportunity such as the Sichuan earthquake presented an occasion to demonstrate their idealism. This idealism is not new-it was also there in the Maoist period, as well as during the Tiananmen Square demonstrations and the hunger strike in May 1989, although those were, of course, different generations of youth with very different belief systems. In the late 1980s, internationalism appeared to be far stronger than patriotism, and some conservative cultural critics in China such as Wang Xiaodong (王小东) labeled student attitudes in those days “reverse racism" (nixiang zhongzu zhuyi, 逆向种族主义), as the students often dismissed much of Chinese culture and government policy and adopted a naïve, pro-Western outlook, ranging from almost total belief in Western media reports from the BBC and Voice of America to a fascination with Western philosophers such as Jean-Paul Sartre, Friedrich Nietzsche, and Sigmund Freud. ${ }^{10}$

\footnotetext{
"Why Grandpa Wen Has to Care; Populist Politics in China," The Economist, June 14, 2008. The original source is a long two-part article by Wu Jiaxiang in Zhongguo qingnian bao [China Youth Daily], April 2, 2008.

${ }^{9}$ On the struggle among Chinese youth to forge an identity, see Ian Weber, “Shanghai Baby': Negotiating Youth Self-Identity in Urban China," Social Identities 8, no. 2 (2002): 347-68.

${ }^{10}$ Shi Zhong, "Chinese Nationalism and the Future of China," translated in Stanley Rosen, ed., "Nationalism and Neoconservatism in China in the 1990s," Chinese Law and Government 30,
} 
Ironically, the more the Chinese government limited information about the West entering China, the more the students, who knew their government was lying about so many developments within China, believed uncritically the Western reporting. ${ }^{11}$

For youth today, the unabashed, uncritical internationalism of the late 1980s has been replaced by what Yongming Zhou has called a new interpretive framework that acknowledges the pursuit of national interest as the ultimate goal of international relations. Within such a "reception context," information emanating from Western media sources is viewed skeptically by well-educated, wellinformed young Chinese, who assume that such reporting is merely attempting to further a pro-Western agenda. ${ }^{12}$

\section{Post-1980s Youth and Their Critics}

Until quite recently, it was common to refer to age groups in China as "generations" (dai, 代), with those coming of age before 1949 constituting the First Generation and those growing up after 1989 the Fifth Generation. However, in another sign of the influence of global trends on China, the Chinese media now refer to generations based on their date of birth, using a concept that originated in Time magazine and was introduced through Chinese literature. Discussions of Chinese youth focus on the "post-1980s generation" (baling hou, 八零后), representing the roughly 200 million Chinese born between 1980 and 1989. ${ }^{13}$ Given the apparent contradictions that mark youth attitudes and behaviors, it is interesting to contrast the assessment of these youth by other generations with their own subjective evaluation. One interesting survey asked those born in the 1960s and 1970s to assess their successors. Table 1 presents the findings, which, not surprisingly, show quite clearly for each of the categories listed that earlier generations see the post-1980s youth as more superficial, self-centered, and materialistic than members of that generation see themselves. These findings are highly congruent with many other surveys published in the Chinese media and with my own interviews. More recently, the Chinese press

no. 6 (November-December 1997): 8-27. A shorter version of this article appeared in Hong Kong's Mingbao yuekan [Mingbao Monthly], no. 9, September 1996. Shi Zhong is the penname of Wang Xiaodong, who led criticism of the film Lust, Caution (色・戒) for its defamation of patriotic students, among other ills.

${ }^{11}$ This assessment is based on travel and interviews throughout China, particularly on college campuses, throughout the 1980s.

${ }^{12}$ Yongming Zhou, "Understanding Chinese Internet Politics," in China and Democracy: A Contradiction in Terms? Woodrow Wilson International Center for Scholars, Asia Program Special Report no. 131, June 2006, 21-25.

${ }^{13}$ The expression is now used in virtually all areas of Chinese life to refer to individuals (e.g., "a post-1980s poet") or phenomena (e.g., "a post-1980s Web site or magazine"). See Zhao Feng, "The Evolution from 'Generations' to 'Post,"” Zhongguo qingnian bao, July 6, 2008, 3. 
Table 1. The post-1980s generation in their own eyes and in the eyes of previous generations.

\begin{tabular}{lcc}
\hline $\begin{array}{l}\text { Attributes of the Post-1980s } \\
\text { Generation }\end{array}$ & $\begin{array}{l}\text { How Pre-1980s } \\
\text { Generations See Them }\end{array}$ & $\begin{array}{c}\text { How the Post-1980s } \\
\text { Generation Sees Itself }\end{array}$
\end{tabular}

Their circle of friends is very large,

$48.6 \%$

$31.4 \%$

but their family circle is very small.

They had their first sexual experience before the age of twenty.

They've been deeply influenced by Japanese anime.

They never drink straight hot water, but only bottled sweetened beverages.

They pay attention to outer appearance and are fussy about how they dress.

From an early age they've grown up eating at Kentucky Fried Chicken and McDonald's.

Their life can't be separated from their great love of the Internet, QQ [instant messaging], and surfing the Web.

They never watch the news or read books.

They don't sleep at night; they're not awake during the day.

They always consider themselves the center of attention.

They don't like to cooperate with others.

They don't want to take on any responsibilities.

They don't like to take the lead in doing things, but always want others to take care of it.

They never defer to others, but always feel that they're really great.

Their concepts of morality, right and wrong, and sense of responsibility are not at all strong.

They always have a high assessment of their own abilities.

They often waste time at 
Table 1. (contd.)

\begin{tabular}{|c|c|c|}
\hline $\begin{array}{l}\text { Attributes of the Post-1980s } \\
\text { Generation }\end{array}$ & $\begin{array}{c}\text { How Pre-1980s } \\
\text { Generations See Them }\end{array}$ & $\begin{array}{l}\text { How the Post-1980s } \\
\text { Generation Sees Itself }\end{array}$ \\
\hline $\begin{array}{l}\text { When they buy things they only } \\
\text { look at the appearance; they're } \\
\text { not concerned with practical } \\
\text { value. }\end{array}$ & $54.2 \%$ & $23.2 \%$ \\
\hline \multicolumn{3}{|c|}{$\begin{array}{l}\text { Source: http://news.sina.com.cn/c/2006-04-03/03598595630s.shtml, published in Jiang Fangbing } \\
\text { "Dui 'baling hou' yidai jiaose piancha wentide tiren yu fansi" [Views and Reflections on Role Devi- } \\
\text { ation of the "Post-80's" Generation], in Zhongguo qingnian yanjiu [China Youth Study], no. 6, June } \\
2007 \text {, p. } 25 \text {. Details on this survey first appeared in Zhongguo qingnian bao [China Youth Daily] } \\
\text { April 3, 2006, where it was noted that the survey arm of the newspaper had collaborated with Sohu } \\
\text { News Center and Sina Women's Channel beginning on March } 26 \text {, 2006, to do an online survey with } \\
\text { a sample size of 3,457 pre-1980s netizens and 6,010 post-1980s youth. }\end{array}$} \\
\hline
\end{tabular}

and online videos have featured a war of words between post-1980s youth, who are just beginning to mature and take their place in Chinese society, and the next generation, the "post-1990s youth," suggesting either the vindication of the familiar expression "Each generation is worse than the last" (yidai buru yidai, 一代不 如一代) or, more likely, that each new generation is eager to push its reluctant predecessors offstage. ${ }^{14}$

The post-1980s generation has been surveyed extensively in the Chinese media, with some of the most interesting surveys addressing political participation and attitudes toward Western culture. Although published studies of political attitudes and participation are of widely varying quality—it is common for pragmatic youth to report politically correct responses-read carefully, these surveys suggest some intriguing behavioral patterns. For example, in its annually published investigation of youth in Beijing, the Beijing Municipal Communist Youth League was very pleased to note that in 2005-2006, around 75 percent of youth expressed a willingness to participate in politics. In previous years, the number had not reached 50 percent. Looking more closely at the findings, however, one finds that only 10 percent were enthusiastic about such participation. More telling is what "participation" actually meant to the respondents. When asked what form their participation had taken, 72.5 percent noted that they had not actually participated at all; 11.1 percent said that participation meant expressing their opinions to family members or friends, followed by 5.8 percent who participated by expressing their opinions in Internet discussions. Only 0.6 percent said that they would contact either a party or youth league

\footnotetext{
${ }^{14}$ Zhang Wei, "The War between Two Labels: A True Record of the 'Post-80's' and 'Post-90's' Attacks," Zhongguo qingnian bao, May 7, 2008, 10.
} 
organization to express an opinion, suggesting how far the party-state apparatus has retreated in the daily lives of most youth. ${ }^{15}$

Another area that is frequently examined is motivation to join the Communist Party. The results often depend on how the question is asked. For example, if asked why they joined the party, respondents are likely to give a politically correct answer. Some surveyors have dealt with this issue by offering a series of choices, ranging from politically correct to instrumental and offering the possibility of choosing up to three reasons, thus allowing the respondent to choose the politically correct answer as well as the "real" reason. Other surveyors have simply asked respondents why they joined and why they thought others around them were joining, with a predictably wide variation dividing their own relatively pure intentions from the self-serving motivations of their comrades. ${ }^{16}$ More recent surveys, presumably reflecting the post-1980s generation's belief that individual desires no longer need to be camouflaged, have elicited what appear to be more honest responses. Party membership is widely desired and considered to be valuable for one's future success, most notably in finding a well-paying job and good housing in a major city, and many youth noted that they were under pressure from their parents to join. In a survey of more than 2,000 students from various universities in $\mathrm{Xi}$ 'an, only 11.5 percent said that they wanted to join the party because they believed in communism; other surveys and interviews have revealed that most applicants have little knowledge or even interest in most party activities and goals. ${ }^{17}$

A major theme in survey research on youth attitudes and behaviors is the inroads that Western culture has made into the belief systems of Chinese youth. One of the more revealing surveys was conducted among 629 history students at thirty-three universities throughout China by the World History Institute of the Chinese Academy of Social Sciences (CASS). The findings were considered too sensitive to be published in the open press and appeared in one of the internal journals published by CASS. Only several of the twenty-one topics queried can be addressed here. In terms of belief systems, 72.7 percent chose "individual struggle" and another 10 percent "did not know" their belief system. Only 17.2 percent opted for "struggle to achieve communism." More than 94 percent acknowledged that they had been influenced by Western

\footnotetext{
${ }^{15}$ Beijing qingnian fazhan baogao [Report on the Development of Beijing Youth], 2005-2006 ed. (Beijing: Renmin chubanshe, 2007), 331-38. There were 742 respondents for this part of the survey.

${ }^{16}$ Stanley Rosen, "The Victory of Materialism: Aspirations to Join China's Urban Moneyed Classes and the Commercialization of Education," China Journal, no. 51 (January 2004): 42-46.

${ }^{17}$ Wang Xingjia, "An Investigation and Analysis of the Ideological and Political Situation of Young Students," Zhongguo qingnian yanjiu [China Youth Study], no. 7, July 2007, 54-56. For a study in Beijing that points up a wide variety of "erroneous views" with regard to motivation for party membership, see Feng Haiyan, "An Investigation into the Motivations for Party Membership among Contemporary University Students,” Zhongguo qingnian yanjiu, no. 6, June 2008, 55-57.
} 
culture, and even though more than 82 percent agreed that Western video products propagate Western political ideas and a Western lifestyle, fewer than 12 percent expressed a willingness to negate such products. Most directly, more than 51 percent identified themselves with American cultural concepts, while around 32 percent said, in effect, that it was a non-issue (wusuowei, 无所 買). Only 17 percent said that they did not identify with these concepts. The surveyors were surprised to discover that more than 61 percent identified with liberalism (ziyou zhuyi, 自由主义) and found it to be a concept of universal moral significance, despite the fact, as the surveyors put it, that everyone knows liberalism is part of Western political thought and the basis of the "democratic system" associated with Western capitalism. In like manner, the surveyors were dismayed to find that close to 36 percent of respondents endorsed the concept of "separation of powers" (sanquan fenli, 三权分立) associated with Western political and legal systems, while more than 20 percent said that they were "uncertain" as to whether they endorsed it; only 44 percent expressed opposition to the concept. On a more positive note, when asked to choose the ten greatest thinkers in world history, Confucius was named on 86.5 percent of the ballots, and Karl Marx was chosen by 82.3 percent. No one else received more than 40 percent. ${ }^{18}$

Other surveys have reinforced many of these findings, particularly in terms of the penetration of American and Western popular culture into the social life of Chinese youth. One national survey of approximately 2,800 individuals ranging in age from eighteen to sixty showed clearly that the celebration of American holidays was correlated directly with age, ranging from a high of 57 percent of those ages eighteen to twenty-five to a low of less than 13 percent for those fiftysix to sixty years of age. ${ }^{19}$

\section{State Initiatives And Youth Responses}

In the aftermath of Tiananmen in 1989, Chinese leaders realized that they had to find a solution to their legitimacy crisis, particularly among rebellious youth. In moving even further from a legitimacy based on ideological criteria to a legitimacy based on performance indicators, "socialism with Chinese characteristics" expanded significantly to embrace cultural and economic forms from the West that previously had been unacceptable to the Communist Party. The strategy has been to make China rich and powerful, raising the standard of

\footnotetext{
${ }^{18}$ CASS Institute of World History Special Topics Group, "A Brief Analysis of a Survey of Young Students with Regard to Belief Systems on 21 Important Questions," Lingdao canyue [Reference reading for leaders], July 5, 2007, 24-28. The other great thinkers chosen, in order, were Mencius, Albert Einstein, Emmanuel Kant, Friedrich Nietzsche, Charles Darwin, Isaac Newton, Stephen Hawking, and Émile Durkheim.

19“'American Holidays: They're Only a Reason to Pass on Good Wishes," Di yishou (第一手), June 24, 2008, http://www.horizonkey.com/showart.asp?art_id=787\&cat_id=6 [accessed February 2, 2009].
} 
living so as to enable increasing numbers of Chinese to enter the middle class while positioning China to be a world-class leader in a variety of areas, including education and science. Youth had to feel that their life chances, particularly in terms of income, employment, housing, and other measures of personal and family success, were steadily improving, and that their country was playing an important role in world affairs. Because performance, unlike ideology, is measurable, Chinese citizens could monitor the state's success in realizing these goals. Many indicators suggest that China has done very well to this point, particularly among urban, well-educated youth, the stratum that posed the greatest threat to regime stability in $1989 .{ }^{20}$ At the same time, in seeking to appease the ambitions of the rising middle class and the new generation of post-1980s and post-1990s youth, who will support state policies if they work, a number of contradictions arising out of these policies have surfaced. Given space considerations, only some representative examples of these new policies and the ensuing reactions can be explored.

In education, at the university level, the Ministry of Education has sharpened the distinctions that divide the best schools from the very good, the good, and the mediocre, and it has designated a small number of elite schools, headed by Tsinghua (Qinghua) and Peking (Beijing) universities, to receive the level of funding that will enable them to achieve world-class status. At the secondary level as well, classes are often tracked by ability, fostering competition and promoting entrepreneurial skills. Moreover, as part of a wide-ranging policy to educate citizens for the twenty-first century, there has been ongoing curriculum reform. The most public controversy has been over the revision of high school history textbooks, with the case of Shanghai widely discussed, to deemphasize such familiar issues as class struggle, socialist ideology, and the historical role played by individual revolutionary leaders in favor of more attention to economics, science and technology, and global trends. At the same time, however, since 1991, there has been an ongoing and, judging from survey research, apparently quite successful "patriotic education campaign," with discourse focusing on the national humiliations of the past, to foster love of the motherland. ${ }^{21}$

\footnotetext{
${ }^{20}$ Recent surveys by CASS suggest that there are about 4 percent to 5 percent of Chinese currently in the middle class (meeting the criteria from several different indicators), with about 10 percent in the cities and 12 percent to 15 percent in the large cities. Perhaps most importantly, many more people subjectively view themselves as middle class than the objective indicators would suggest, a sign of government success. See Lingdao canyue [Reference reading for leaders], December $5,2007,16-20$. One survey found that although more than 80 percent did not currently view themselves as middle class, more than 43 percent thought there was a very real possibility that they would enter the middle class in the next ten years. See Zhongguo qingnian bao, December 24, 2007,2 .

${ }^{21}$ On the controversy over high school history textbooks, see Joseph Kahn, "Where's Mao? Chinese Revise History Books," New York Times, September 1, 2006. For the backlash against this new emphasis, see "Shanghai History Textbook Controversy, Revisited," Shanghaiist, September 14, 2007, http://shanghaiist.com/2007/09/14/shanghai_histor.php [accessed January 26, 2009].
} 
There have also been attempts to promote political education in a manner that might appeal to technology-savvy youth, with somewhat mixed results. For example, in September 2008, following the positive images generated by the response to the Sichuan earthquake and the success of the Olympic Games, People's Daily launched an official fan site dedicated to the president and premier, seeking to provide patriotic cyberyouth with a "cool place to visit." 22 Another strategy has been the marketing of computer games to the online world that substitute model Communist soldiers such as Lei Feng or other acceptable historical figures for heavily armed superheroes and reward players for doing good deeds instead of gunning down evildoers; the response reportedly has also been "cool," but not in the positive sense. ${ }^{23}$ In keeping with many surveys and interviews that suggest the values of contemporary youth run toward individualism and resistance to such prepackaged, politically correct role models, those who have achieved "idol" (ouxiang, 偶像) status include "Supergirl" contest winner Li Yuchun, who was chosen in an "open" election. Criticized by establishment voices for her quirky personality, mediocre voice, and androgynous appearance, these same attributes were considered positives by the more than 3.5 million voters who chose her. Another popular youth icon is Han Han, a handsome twenty-six-year-old writer and race car driver whose rebellious attitude, conspicuous consumption, and witty posts have made him the "ultimate symbol of instant individual gratification" and his blog on sina.com the most accessed. This resistance to authoritative voices is common in other areas, including the widespread use of "spoofing" (egao, 恶搞), in which youth transform popular or well-known media content into something politically or culturally subversive. ${ }^{24}$

Despite the multiple anniversaries of significant events that fall in 2009, it appears unlikely that Chinese youth will pose any immediate threat to the regime. In pursuing a pragmatic, success-oriented approach, the post-1980s generation has ensured that their public lives are placed in service to their private ambitions. As noted, their "participation" in politics has, in effect, been a private participation, through friends, family, and in anonymous Internet activities. Their pursuit of party membership has been merely a necessary investment to increase their chances of finding a good job and leading a comfortable life.

\footnotetext{
${ }^{22}$ South China Morning Post, September 9, 2008.

${ }^{23}$ Ching-Ching Ni, "Will China's Youth Play Virtuous Virtual Game?” Los Angeles Times, November 4, 2005 .

${ }^{24}$ Surveys and discussions on "idol worship" and spoofing are featured heavily in academic journals and the mainstream press. On spoofing, see Ashley Esarey and Xiao Qiang, "Political Expression in the Chinese Blogosphere," Asian Survey 48, no. 5 (September-October 2008): 764-65. The influence of blogs, including Tencent's Q Zone, Douban, Tianya.cn, 80 Hoo, and the Sina and Sohu blog portals on Chinese youth, could form the basis of a separate article. I am grateful to Rebecca Mackinnon and Xiao Qiang for introducing me to some of these blogs. See also Yunxiang Yan, "Little Emperors or Frail Pragmatists? China's '80ers Generation," Current History, September 2006, $255-62$.
} 
There are few indications that this generation of youth will take any overt political risks, particularly if the leadership remains unified.

At the same time, however, given the increasing politicization of protests and the potential for economic problems to call heightened attention to social inequalities and tensions that have simmered just below the surface, party leaders will be monitoring these anniversaries closely, seeking to ensure that "idealistic" youth do not link up with disgruntled migrant and other laid-off workers. In the longer term, the rising expectations of China's youth and the middle class, and the still-relevant legacy of youth activism, will continue to pose challenges for a government that has staked its legitimacy on deliverable performance criteria. Success in the future will require the continuing expansion of middle-class opportunities for youth now entering the workforce and the expected rise of China to world-power status, particularly because, as surveys show, a majority in China expect their country to overtake the United States as the world's leading superpower. ${ }^{25}$

${ }^{25}$ Pew Global Attitudes Project: China Survey, July 22, 2008, 19-20. 